\title{
CONTROLLING DEFORMATION INHOMOGENEITY IN THE ACCUMULATIVE ANGULAR DRAWING PROCESS ASSISTED BY CONSTITUTIVE AND MULTISCALE NUMERICAL MODELLING
}

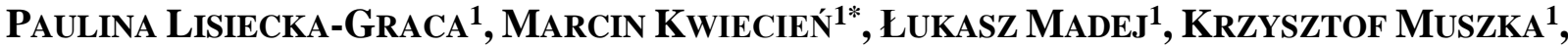 \\ JANUSZ MAJTA ${ }^{1}$, BRADLEY P. WYNNE ${ }^{2}$ \\ ${ }^{1}$ AGH University of Science and Technology, al. Mickiewicza 30, 30-059 Krakow, Poland \\ ${ }^{2}$ The University of Sheffield, Mappin St, S1 3JD Sheffield, United Kingdom \\ *Corresponding author: mkwiecie@agh.edu.pl
}

\begin{abstract}
Ultrafine-grained structure was produced in the Accumulative Angular Drawing (AAD) process in which the complex strain path was applied. The microalloyed steel wire rods were produced using multi-pass wire drawing process where the high strain accumulation is used as a way to achieve much higher microstructure refinement level compared to the conventional wire drawing (WD) process. The wires after both AAD process and WD process were examined in order to assess mechanical properties and microstructure development. In order to evaluate the effects of complex deformation on microstructure development and mechanical properties of the drawn wires, a numerical model of the torsion tests was applied using Abaqus software. The cyclic torsion tests were performed to study the effects of the applied hardening rule - described as a function of dislocations density and the accuracy of the prediction of material behaviour subjected to strain path change during AAD. It has been shown that an additional advantage of presented approach is its capability of tracking evolution of dislocation density during the deformation process. The initial dislocation densities used in the performed calculations were taken from the microstructural analysis using high resolution EBSD. During strain reversal, annihilation of the dislocations (Bauschinger effect) is a common phenomenon that leads to the decrease in dislocation density and affects the final strength. Finally, based on the proposed constitutive description, multiscale finite element modelling combined with Digital Material Representation (DMR) was used as a tool for prediction of the deformation and microstructure inhomogeneity in the drawn wires.
\end{abstract}

Key words: Accumulative Angular Drawing; Physically-based modelling; Multiscale model; Digital Material Representation

\section{INTRODUCTION}

Steel remains the main constructional material that finds its use in most of the branches of the industry. Therefore, researchers are still chasing with new ways of its production and methods of further improvement of the properties. In parallel, ultrafinegrained (UFG) materials have been the object of intense research around the world for the last couple of decades. Hence, it is a natural consequence that advanced structural steels are produced using new techniques that offer new properties for complex applications. Basing on many researches (Schmitt et al.
2018; Song et al., 2000) it can be stated that reduction in the grain size leads to significant enhancements in strength, toughness and fatigue resistance. The main problem that scientists are coming across is the good balance between high strength and good ductility of new UFG materials. Extensive research focus has been put on the processes that give possibility to produce such materials. As far as steels are concerned there are already ways to refine their structure to the submicron range through the severe plastic deformation (SPD) (Harsha et al., 2018) and advanced thermomechanical processing (ATP) (Zhao \& Jiang, 
2018) methods. Another approach for the manufacturing routes is combining those two techniques. For example, recently developed accumulative angular drawing (AAD) (Wielgus et al., 2010; Muszka et al., 2013; Majta et al., 2014) combined with wire drawing (WD) and subsequent heat treatment process may be employed and effectively used to induce SPD effects in microalloyed steel wires. The AAD process can be characterized as a novel process which applies during drawing not only reduction of the area but also banding, shearing and burnishing which induces complex strain path history to the wires. The AAD is characterised by a number of process parameters that influence the level of deformation and microstructural inhomogeneity. Hence, numerical modelling of deformation behaviour of wires drawn using this technology seems to be a natural way of better understanding and optimisation of the process. However, numerical simulation of processes characterised by complex loading conditions needs a proper description of material hardening model (Sellars, 2011; Muszka et. al, 2008). Especially in the case of complex steels, modelling approach should include all major mechanisms that are responsible for the material deformation and strengthening. Finite element simulation offers a tool for explicit representation of the microstructure e.g. thanks to the approach known as Digital Material Representation (DMR) (Madej et al., 2011). It can be combined within the multi scale model and successfully used for simulation of metal forming processes characterised by complex thermo-mechanical states.

In the presented study, to investigate the most important effects that occur during strain path changes the physically based model is proposed and implemented in the multi scale finite element model.

\section{EXPERIMENTAL PROCEDURE}

The Accumulative Angular Drawing (AAD) process was carried out in order assess the effects of complex deformation on mechanical properties and microstructure development of the low carbon and microalloyed steels. The chemical compositions of both materials are presented in the table 1 . The initial materials were the wire rods of $6.5 \mathrm{~mm}$ in diameter in the as-hot rolled conditions. Wire rods were deformed using multi-pass wire drawing process where the high strain accumulation was used as a way to achieve much higher microstructure refinement level compared to the conventional wire drawing process. In the AAD process, three deformation passes were applied and final wire diameter was $4.0 \mathrm{~mm}$. Total strains of $0.45,0.38$ and 0.30 were applied in the first, second and third stage, respectively, followed by the calibration stage with the strain of 0.14 . Although, the AAD design allows for various combinations of die positioning to be used. The present study was concentrated on the stepped die positioning (Wielgus et al., 2010), in which the offset from the drawing line between successive dies was equal to $10^{\circ}$. Additionally, after first stage, each wire was rotated by $180^{\circ}$ to obtain axi-symmetrical distribution of strain accumulation at the cross-section of a final product. The scheme of the AAD process is presented in the figure 1. Additionally, in order to compare the effects of the AAD process with conventional process, the linear wire drawing (WD) was also carried out. Furthermore, wires after both drawing processes were annealed in $500^{\circ} \mathrm{C}$ for 10 minutes and after annealing cooling was performed in the air.

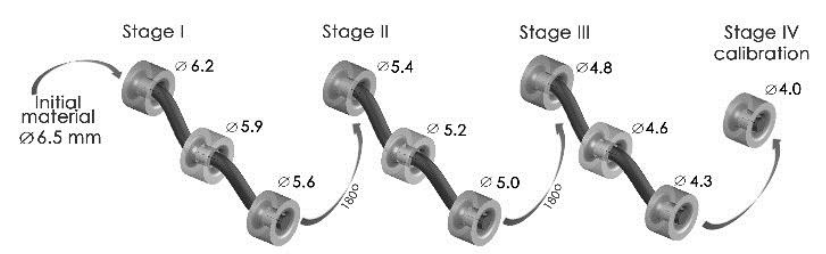

Fig. 1. Scheme of the 3 stages stepped $A A D$ process and the calibration stage.

Materials produced in all above-mentioned deformation schedules were subjected to microstructure analysis and mechanical testing. Obtained results were used for validation of further multiscale modelling and constitutive description.

The changes in the microstructure were observed using optical ZEISS Axio Imager M1m microscope. Additionally, texture measurements were performed using EBSD/SEM technique. The EBSD data were collected using a FEI field emission gun scanning electron microscope (FEGSEM) equipped with EDAX EBSD camera. TSL software was used for data acquisition while HKL Channel 5 software package was used for analysis. TEM was analysed using thin foils with the JEOL JEM2010 ARP microscope. Mechanical properties represented by the stress-strain curves were obtained using ZWICK Z250 testing machine. The specimens of $80 \mathrm{~mm}$ gauge length were cut from the wires after each stage of deformation and the tensile tests were performed under the quasi-static conditions. 
Table 1. Chemical composition of the investigated materials.

\begin{tabular}{|c|c|c|c|c|c|c|c|}
\hline Material & $\mathrm{C}$ & $\mathrm{Si}$ & $\mathrm{Mn}$ & $\mathrm{Nb}$ & $\mathrm{Ti}$ & $\mathrm{Cu}$ & $\mathrm{N}$ \\
\hline $\mathrm{Nb}-$ steel & 0.07 & 0.29 & 1.36 & 0.067 & 0.03 & 0.16 & 0.0098 \\
\hline LC-steel & 0.05 & 0.185 & 0.51 & - & - & 0.14 & 0.006 \\
\hline
\end{tabular}

\section{RESULTS}

As the result of application of the novel AAD process, nanostructures were produced using SPD effects. Grains, subgrains, dislocation cells and precipitates frequently associated with dislocations are the most important microstructural features observed in these materials. The previous results showed that the strain path applied in the AAD process affects directly the changes of the microstructure and texture as well as the mechanical properties in the final product. The main reason for such structure development is that the accumulation of strain is obtained not only from the reduction of area but also strain accumulation in the outer part of the wire due to double bending of the wire after each die and the shearing effect during the deformation. Because of that the grain refinements observed after the deformation processes were different in the surface and in the core of the wires.
Much stronger grain refinement is observed near the wire surface, where the grains were smaller than 200 $\mathrm{nm}$, while in the centre of the wire grains of the diameters of $1 \mu \mathrm{m}$ are observed (figure 2).

Deformation applied to the wires caused that the spacing between the boundaries of the grains of the lamellar structure decreases and a lamellar structure is uniformly developed in the specimen after AAD process. It was also found that there are some areas where irregular lamellar structure was produced (figure $3 \mathrm{a}$ ), due to the presence of fine second phase particles. Another noticeable phenomenon observed in severely deformed wire specimens is damage of pearlite during applied processing, resulting in the refinement of the pearlite colonies (figure $3 \mathrm{c}$ ) what, as should be expected, directly leads to increased ductility and decreased strength of the investigated material.
Initial wire rod

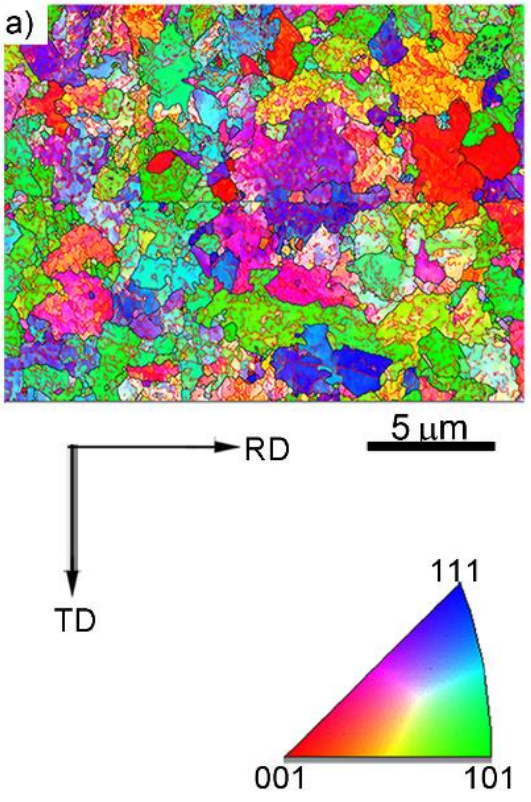

After AAD
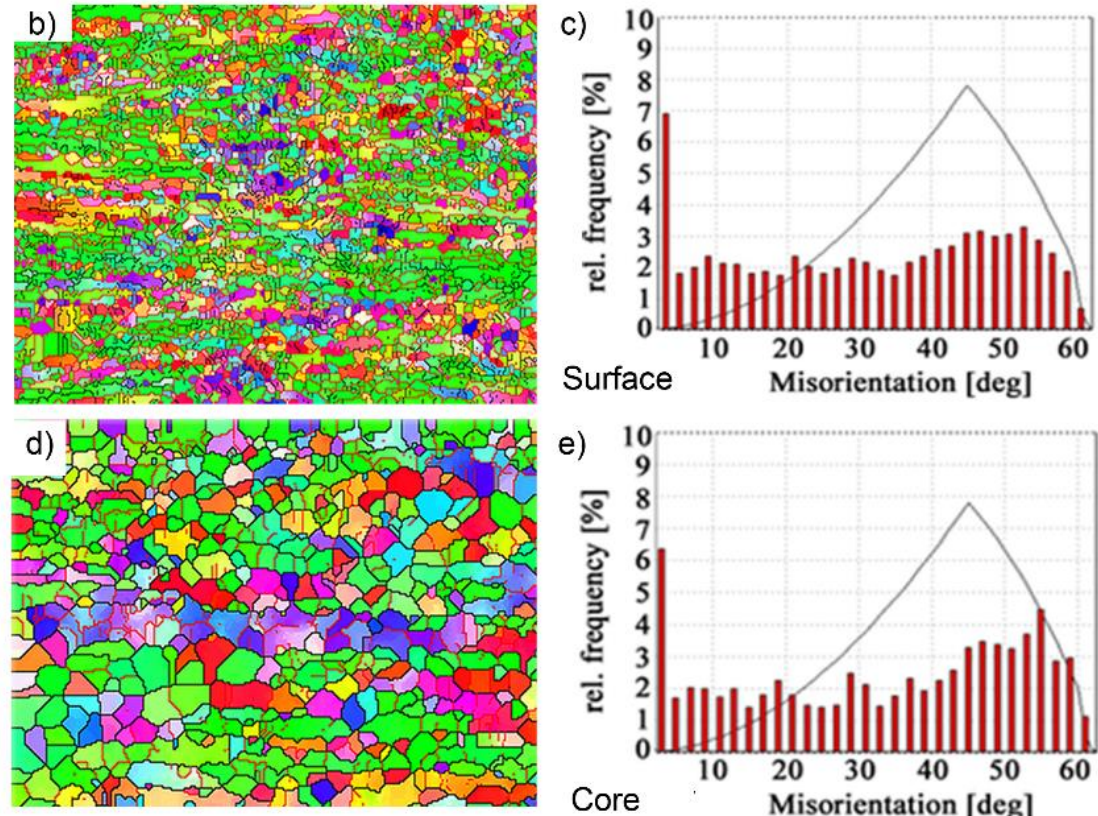

Fig. 2. The IPF maps of the microalloyed steel as received a); and after AAD in the surface $b$ ) and in the core of the wire rods -d) (black line - high angle boundaries; red line -low angle boundaries). Misorientation angle measured in the surface -c) and in the core-e). 

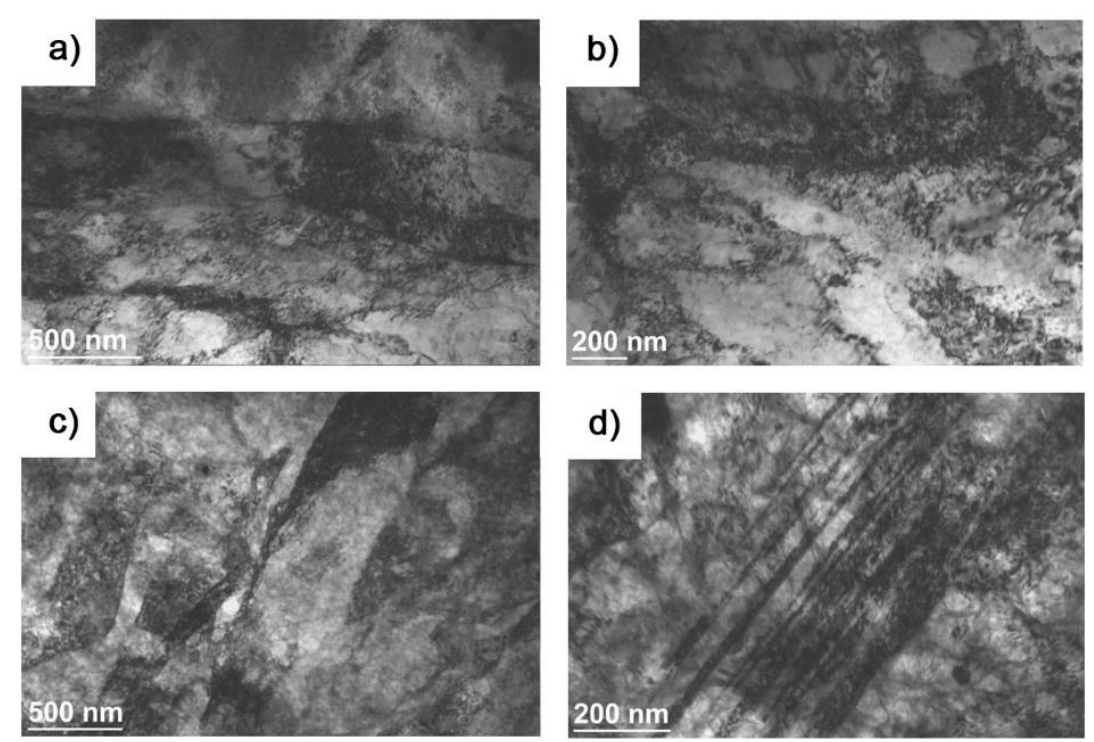

Fig. 3. Examples of TEM images of the microalloyed steel after AAD process. Lamellar structure in the surface of wire rods a, $b$ ) and in the core of material $-c, d$ ).

It can be observed that with increasing accumulation of the strain in the severely deformed specimens the grains are elongated what is clearly visible in the near surface region (figure $3 \mathrm{a}, \mathrm{b}$ ). Additionally, in the outer area of wires an extensive dislocation substructure is observed. As the effect of applied strain path dislocation structure is developed in the core but in the lower level comparing to the surface area (figure $3 \mathrm{c}, \mathrm{d})$. Summarizing, specimens obtained by the process which apply SPD effects show inhomogeneous, ultrafine and elongated microstructure with significant amount of dislocation substructure.

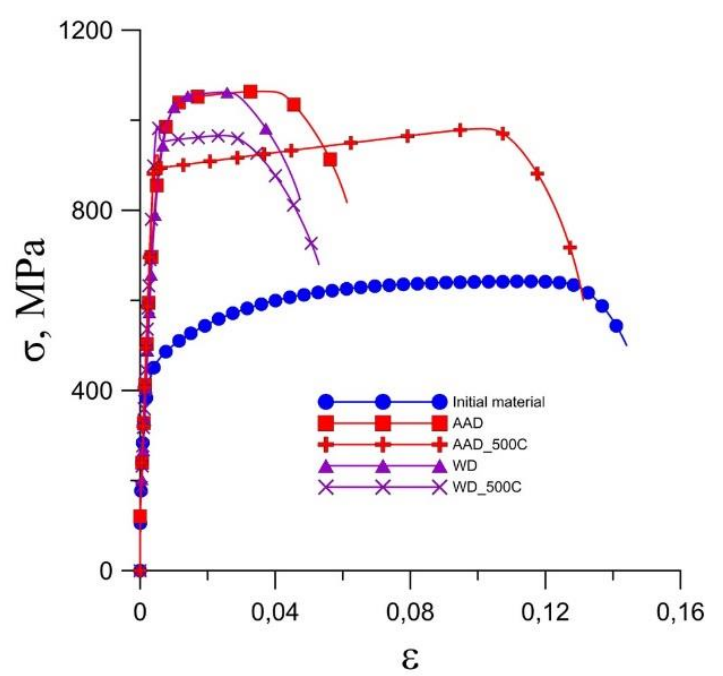

Fig. 4. Mechanical properties of microalloyed steel wire rods after $A A D$ process and $W D$.

It is well known that improving strength and ductility as a result of the complex metal forming processing is very difficult. Application of the complex deformation modes (AAD), instead of typical wire drawing (WD), results in the improvement of both strength and ductility (figure 4). Additionally, during AAD process it is possible to control the inhomogeneity of the microstructure and deformation level by changing the angle between dies. In the present work after deformation it is observed that strength measured in the tensile tests increase equally. Application of the combined metal forming processing (AAD) increases the workability of the drawn wires, comparing to the conventional wire drawing (WD). The obtained results clearly show that the applied complex metal forming processes increases strength of the investigated material and also leads to the increase ductility what is crucial for further deformation. This may be caused by the fact that the accumulated deformation energy was sufficient for the beginning of the in-situ recrystallization. As a result the restoration process of ductility was observed. Another important issue in the case of AAD process is that we can obtained UFG microstructure, which is produced first of all in the outer layers of microalloyed ferrite specimens. Such structure causes enhancement of the fatigue properties due to the large number of grain boundaries, which impede crack propagation. The most visible effect of AAD process comparing to the WD process is observed after heat treatment of wires after deformation process. The annealing process of the wires was conducted in both cases at $500^{\circ} \mathrm{C}$. Heat treatment process caused that changes of the mechanical properties are more visible in the AAD wires than in the WD wires. First of all the strength of the WD wire is higher than in the case of wires after AAD process but in the same time its ductility is much lower. 
What is more the ductility of the wires after AAD process is comparable to the initial material. These differences were caused by the accumulated energy after deformation process and by the inhomogeneity of the structure in the wires after AAD process.

\section{MODELLING}

Due to the complexity of the AAD (a number of process parameters that influence inhomogeneity of microstructure evolution and deformation), numerical modelling can provide a robust tool for optimisation of process parameters. It has been already identified that deformation processes with complex strain paths require properly built flow rule (Muszka et al., 2008). Simple isotropic hardening does not take into account flow softening due to Bauschinger effect. Therefore, more complex models e.g. combined kinematic-isotropic hardening flow rule are developed (Graca et al., 2014). Another modelling approach includes flow rules based on internal variables e.g. representing dislocation density changes during deformation. In the current study, numerical model of the torsion tests were build using Abaqus Standard software. The presented work hardening model was implemented using UHARD subroutine. The basic assumption of the model is that the total dislocation density can be describe as a sum of the two components following way:

$$
\rho_{t}=f \rho_{w}+(1-f) \rho_{c}
$$

where: $\rho_{w}$ is a dislocation density in the cell walls, $\rho_{c}$ is a dislocation density in the cell interiors and $f$ is a volume fracture in the cell walls.

Generally, the dislocations in materials can be divided in to those which from the cellular structure and dislocations in the cell interiors. The dislocation density changes in the cell walls can be written by equation (2) and the dislocation density changes in the cell interiors can be described in the following equation (3) (Toth et al., 2002):

$$
\begin{aligned}
\dot{\rho}_{w} & =\frac{6 \beta^{*} \dot{\gamma}_{c}(1-f)^{2 / 3}}{b d f}+\frac{\sqrt{3} \beta^{*} \dot{\gamma}_{c}(1-f) \sqrt{\rho_{w}}}{f b} \\
& -k_{0}\left(\frac{\dot{\gamma}_{w}}{\dot{\gamma}_{0}}\right)^{-1 / n} \dot{\gamma}_{w} \rho_{w}
\end{aligned}
$$

$$
\begin{aligned}
\dot{\rho}_{c} & =\alpha^{*} \frac{1}{\sqrt{3}} \frac{\sqrt{\rho_{w}}}{b} \dot{\gamma}_{w}-\beta^{*} \frac{6 \dot{\gamma}_{c}}{b d(1-f)^{1 / 3}} \\
& -k_{0}\left(\frac{\dot{\gamma}_{c}}{\dot{\gamma}_{0}}\right)^{-1 / n} \dot{\gamma}_{c} \rho_{c}
\end{aligned}
$$

The meaning of the variables in the presented equations is the following: $\alpha^{*}$ is a factor characterizing the Frank-Read source, $b$ is the Burgers vector, $\beta^{*}$ is a factor characterized friction of dislocation glide, $k_{0}$ is constant and $n$ is the strain rate sensitivity of annihilation process.

In presented model, the formula for the shear stress based on Taylor equation was used:

$\tau=\tau_{0}+\alpha G b \sqrt{\rho_{t}}$

where the total dislocation density can be described by equation (1).

In order to take into account, the precipitation hardening process observed in microalloyed ferrite the precipitation hardening formula term based on the Orowan-Ashby equation was added. The final formula, which describes the overall stress, was based on the RGB model (Rauch et. al, 2007) and can be written as follows:

$$
\begin{aligned}
\sigma= & \left(\sigma_{0}+M\left[X+(1-\alpha)\left(\tau-\tau_{0}\right)\right]\right) \\
& +\left[\beta \frac{f^{1 / 2}}{\kappa} \ln \left(\frac{\kappa}{6.125 \times 10^{-4}}\right)\right]
\end{aligned}
$$

where $\sigma_{0}$ is the initial stress, $M$ is the Taylor factor, $\tau_{0}$ is the stress related to lattice friction and solute contents, $X$ is the internal variable describing rapid changes in the stress under strain path changes, $f$ is the precipitation volume fraction and $\kappa$ is the precipitation diameter.

Figure 5 presents the comparison between the calculated and measured flow curves for low carbon and microalloyed steel during cold deformation cyclic torsion tests. The cyclic forward/reverse torsion tests were carried out at room temperature using cylindrical specimens (gauge length of $20 \mathrm{~mm}$ and gauge diameter of $10 \mathrm{~mm}$ ) from the materials presented in table 1. Arbitrary strain path (ASP) machine was used and both materials were subjected to the following deformation schedule: 4 cycles of forward/reverse torsional deformation with equivalent strain of 0.25 per pass. The total equivalent strain of 2 was measured at the effective radius $(0.724 R)$ in the torsion test (Sun et al., 2013). The deformation process was performed at the constant strain rate of $0.1 \mathrm{~s}^{-1}$. 

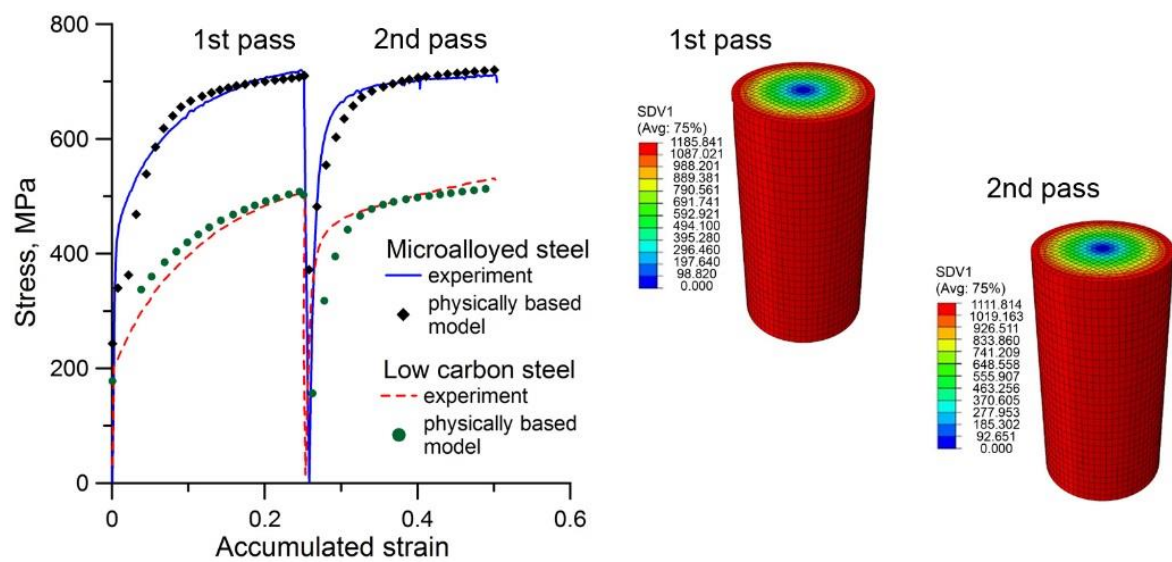

Fig. 5. Comparison of the measured and calculated flow stresses using physically based model for both analysed materials (a) and Mises stress map distribution obtained in numerical simulation for microalloyed steel ( $b$ ).

The results obtained using proposed equation set are characterized by a good prediction of flow stress for the both analysed materials. It is a very important especially in the case of the microalloyed steel where the flow stress is a sum of dislocation strengthening and precipitation strengthening. Additionally, as it can be expected a better result was obtained for the first pass of the deformation process, what confirms how difficult the correct prediction of the materials behaviour is when the Bauschinger effect occurred

During the cyclic deformation process, the dislocations created at the first stage are annihilated upon strain reversal. Hence, the total dislocation density decreases due to the Bauschinger effect. It was also observed that the dislocation density starts to increase with increasing reverse deformation at the second stage of the torsion test. In order to obtain a good prediction of the flow stresses at the reloading stage, the most important part of the approach is an adjustment of the dislocations evolution rate in the cell walls and in the cell interiors. The initial dislocation density used in the performed calculation has been taken from the microstructural analysis (figure 6). The particular methodology and microstructure analysis have been presented as well in (Lisiecka-Graca et al, 2019).

Additional advantage of the presented approach is its capability of tracking evolution of the dislocations density during the deformation process (figure 7). The presented curves were obtained using formula for the dislocation density in the cell walls (equation (2)) and in the cell interior (equation (3)), the total dislocation density was obtained by equation (1). The dislocations density calculated for the low carbon steel are qualitatively similar, but the level of the values was lower than in the case of the microalloyed steel.

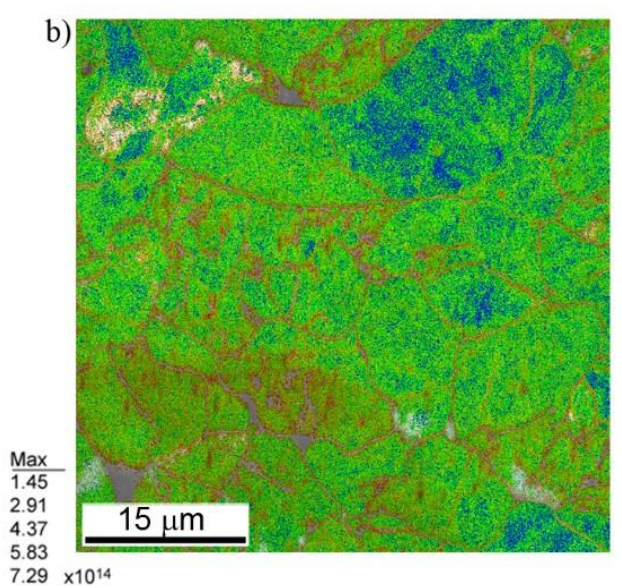

Fig. 6. The distribution maps of geometrically necessary dislocation density (GND) for the low carbon steel (a) and microalloyed steel (b) (Lisiecka-Graca et al., 2019).

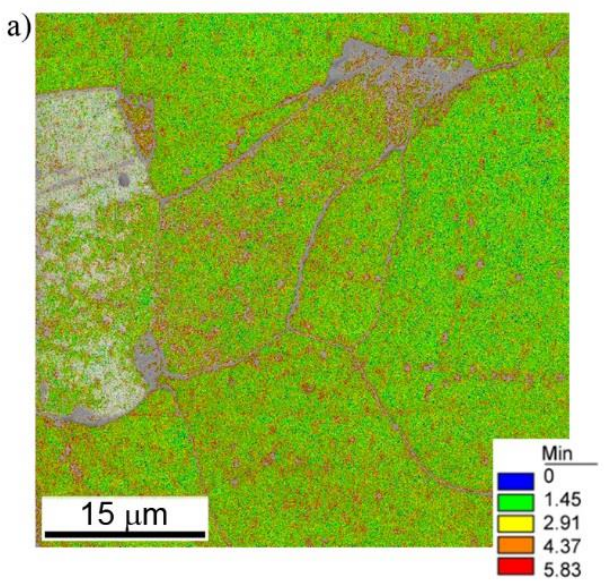




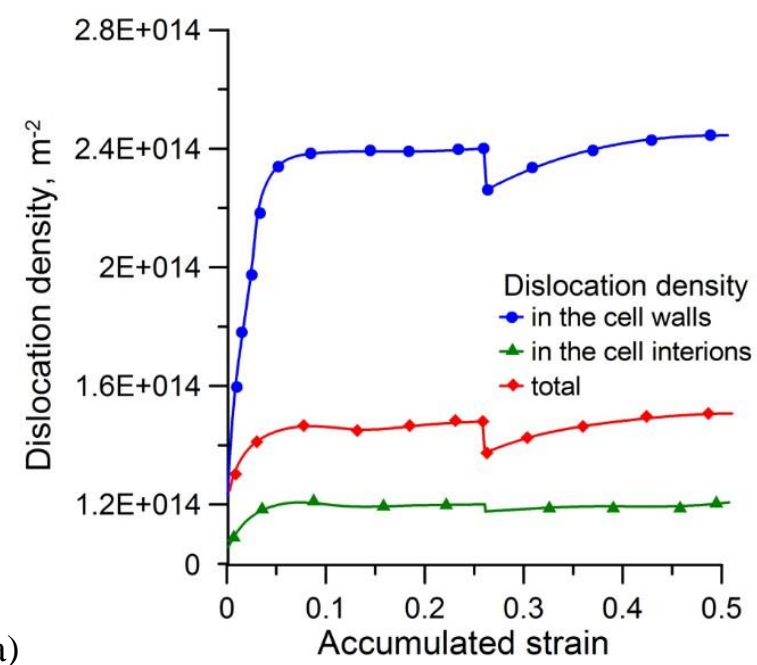

a)

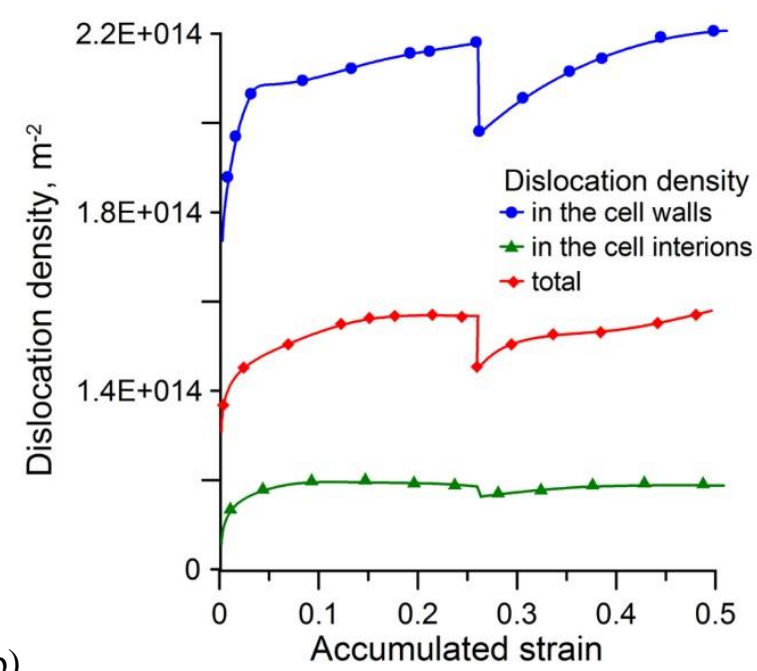

b)

Fig. 7. The evolutions of dislocations density that accompanies the Bauschinger effect, calculated for the microalloyed - a) and low carbon -b) steels.

\section{MULTISCALE MODEL OF THE AAD PROCESS}

Developed hardening model can be utilized in the numerical simulations of processes characterized complex loading conditions. In the present work, it is used for numerical simulation of the AAD process. In the simulation, similar conditions to experimental ones were applied. Material was assumed to be low carbon steel (Muszka, 2013). At macro scale, combined isotropic-kinematic hardening law was implemented - model parameters were adopted from the previous Authors work (Graca et al., 2014). At micro scale, UHARD user subroutine was used to implement the developed physically-based hardening rule presented in the previous chapter. Figure 8 schematically presents the idea of the multi scale model that was developed in Abaqus software. In order to create multi scale model, submodelling technique was applied. At first, simulation of the AAD process was run at the macro scale. Then, displacements of the selected finite element nodes were extracted and used as the boundary conditions in the first submodel. This way locally more detailed solution was obtained. Finally, second submodel was created - this time it consisted of 5 unit cells that were placed at marked positions at the cross-section of the Submodel 1 (see figure 8). In order to study the deformation inhomogeneity during the AAD process at micro scale, unit cells were created using Digital Material Representation (DMR) approach (Madej et al., 2011; Muszka \& Madej, 2013). DMR unit cells were of the size of 100 x 100 x 100 microns and consisted of 100 grains each. In order to take into account difference in crystallographic orientation of the grains, different properties were assigned to each grain - by diversification of the hardening model parameters - and random assignment of them to each grain according to the gauss distribution.

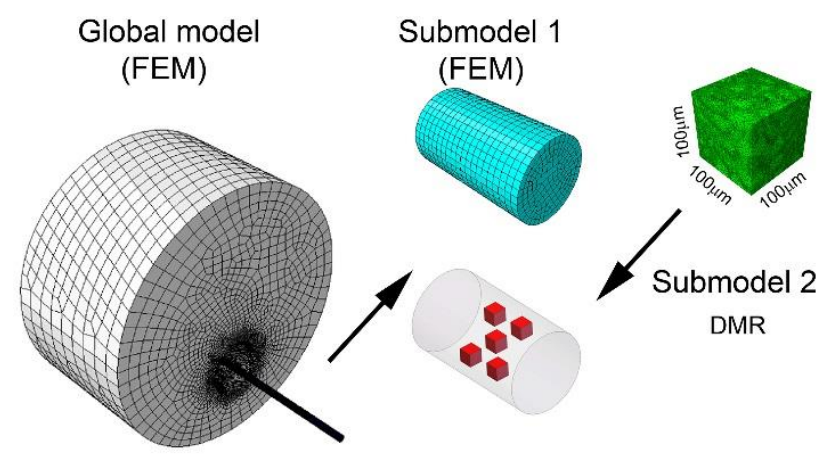

Fig. 8. FEM model of AAD process.

Figure 9 presents Mises stress distribution during accumulative drawing that were calculated at macro scale. Stress in homogeneity resulting from the specific deformation modes that are characteristic for the AAD process (area reduction, torsion, bending, burnishing), is visible both at the longitudinal and transverse cross sections.

Example of calculation results of equivalent plastic strain distribution at micro scale is presented in figure 10. It can be seen, that application of the submodelling with implemented DMR approach, allowed for much more detailed prediction of strain inhomogeneity in ultra-fine grained structure. Plastic strain gradients at various positions in the wire cross section can be visible- especially in the area of the wire that was subjected to additional shear and bending (are close to the right surface of the wire). 

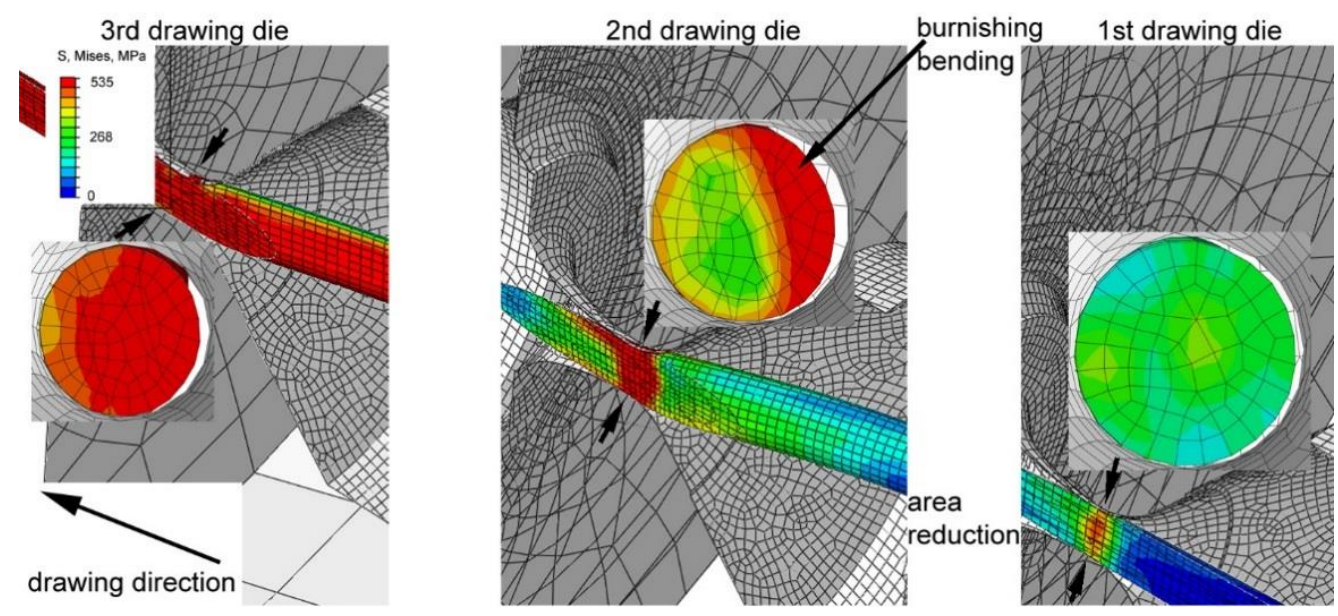

Fig. 9. Mises stress distribution maps at longitudinal and transverse cross-sections of the drawn wire - macro scale model.

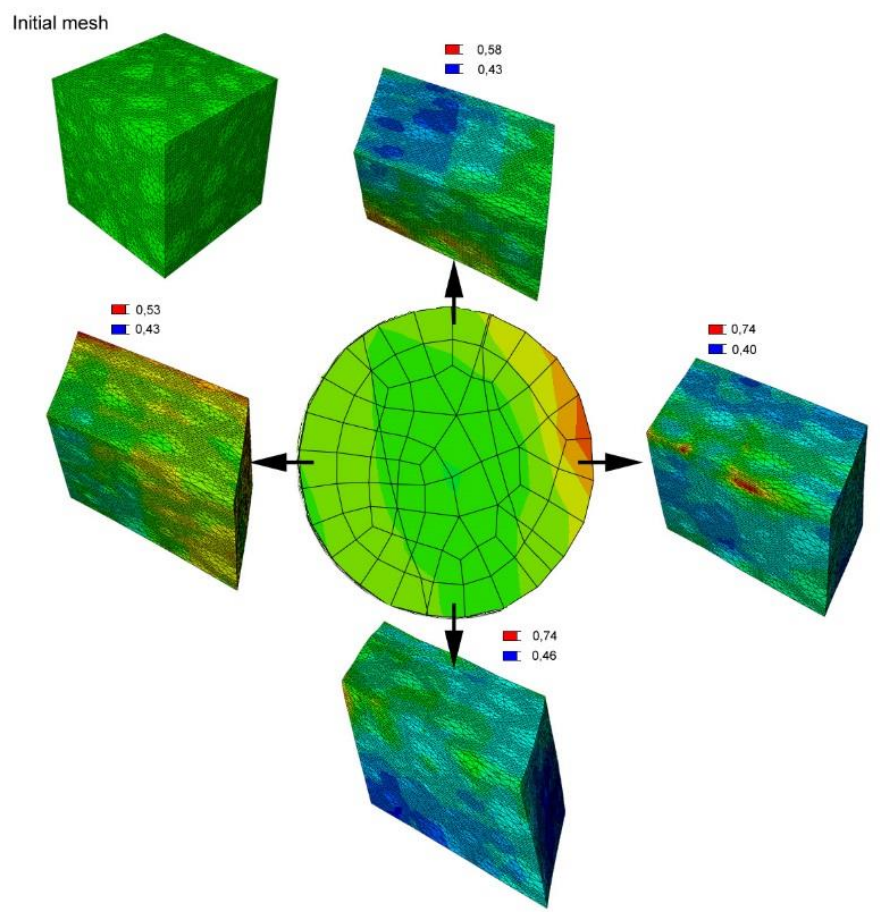

Fig. 10. Inhomogeneity of equivalent plastic strain distribution in the third drawing die of the AAD process.

\section{CONCLUSIONS}

Based upon results from the presented research the following major conclusions can be drawn:

- Application of the AAD process allows control of deformation and microstructural inhomogeneity in the drawn wires. As a result, it is possible to control the mechanical properties of the final products and obtain wires with better combination of strength and ductility compared to typical wire drawing processes.

- The beneficial use of the AAD process is especially visible in the case of microalloyed steel where sig- nificant effects of several strengthening mechanisms play an important role in the creation of inhomogeneity of both deformation and mechanical properties.

- Application of the properly built, multiscale numerical model allows for accurate prediction of strain inhomogeneity, what can be used for optimisation of process parameters towards controlled inhomogeneity of microstructure in the AAD process.

- Necessary step is also a development of material hardening model that is sensitive to complex changes of loading directions. In the presented 
work, physically-based hardening model was developed and tuned using cyclic torsion test. It was then successfully applied in the simulation of the AAD process at the micro scale using Digital Material Representation approach. It allowed much more precise numerical simulation compared to the simple thermos-mechanical model

\section{ACKNOWLEDGMENTS}

This work was supported by the project no 16.16.110.663 task no 3 .

\section{REFERENCES}

Graca, P., Muszka, K., Majta, J., Stefańska-Kądziela, M., Dziedzic, D., Kwiecień, M., 2014, Mechanical response of microalloyed steel subjected to nonlinear deformation, $\mathrm{Key}$ Engineering Materials, 622-623, 314-321.

Harsha, R.N., Mithun Kulkarni, V., Satish Babu, B., 2018, Severe Plastic Deformation - A Review, Materials Today: Proceedings, 5, 22340-22349.

Lisiecka-Graca, P., Muszka, K., Majta, J., 2019, Assessment of the strengthening mechanisms operating in microalloyed steels during cyclic deformation using high resolution electron backscatter diffraction, TMS 2019: 148th annual meeting \& exhibition supplemental proceedings, San Antonio, 537-547.

Madej, Ł, Rauch, Ł., Perzyński, K., Cybułka, P., 2011, Digital Material Representation as an efficient tool for strain inhomogeneities analysis at the micro scale level, Archives of Civil and Mechanical Engineering, 11(3), 661-679.

Majta, J., Muszka, K., Kwiecien, M., Stefańska-Kądziela, M., Graca, P., 2014, Characterization of UFG microalloyed steel produced by combined SPD treatment, Key Engineering Materials, 622-623, 249-256.

Muszka, K., Perzyński, K., Madej, Ł., 2008, Application of the cyclic plasticity hardening law to metal forming, Computer Methods in Materials Science, 8(4), 165-170.

Muszka, K., 2013, Modelling of deformation inhomogeneity in the angular accumulative drawing process - multiscale approach, Materials Science and Engineering A, 559, 635642 .

Muszka, K., Madej, Ł., 2013, Application of the three dimensional digital material representation approach to model microstructure inhomogeneity during processes involving strain path changes, Computer Methods in Materials Science, 13, 258-263.

Rauch, E.F., Gracio, J.J., Barlat, F., 2007, Work-hardening model for polycrystalline metals under strain reversal at large strains, Acta Materialia, 55, 2939-2948.

Sellars, C.M., 2011, From trial and error to computer modelling of thermomechanical processing, Ironmaking \& Steelmaking, 38, 250-257.

Schmitt, J.-H., Iung, T., 2018, New developments of advanced high strength steels for automotive applications, Comptes Rendus Physique, 19, 641-656.

Song, R., Ponge, D., Raabe, D., Speer, J.G., Matlock, D.K., 2000 , Overview of processing, microstructure and mechanical properties of ultrafine grained bcc steels, Material Science and Engineering A, 441, 1-17.

Sun, L., Muszka, K., Wynne, B.P., Palmiere, E.J., 2013, On the interactions between strain path reversal and dynamic recrystallisation in 316L stainless steel studied by hot torsion, Material Science and Engineering A, 568, 160-170.

Toth, L.S., Molinari, A., Estrin, Y., 2002, Strain hardening at large strains as predicted by dislocation based polycrystal plasticity model, Journal of Engineering Materials and Technology, 124, 71-77.

Wielgus, M., Majta, J., Łuksza, J., Paćko, P., 2010, Effect of strain path on mechanical properties of wire drawin products, steel research international, 81, spec. issue, 13th Int. Conf. Metal Forming, Toyohashi, 490-493.

Zhao, J. Jiang, Z., 2018, Thermomechanical processing of advanced high strength steels, Progress in Materials Science, $94,174-242$

\section{KONTROLOWANIE NIEJEDNORODNOŚCI ODKSZTALCENIA W PROCESIE KATOWEGO WIELOSTOPNIOWEGO CIACGIENIA WSPOMAGANE MODELOWANIEM KONSTYTUTYWNYM I SYMULACJĄ WIELOSKALOWA}

\section{Streszczenie}

W pracy przedstawiono badania wpływu złożonej ścieżki odkształcenia na rozdrobnienie mikrostruktury w drutach poddanych procesowi Kątowego Wielostopniowego Ciągnienia (AAD Accumulative Angular Drawing). Druty ze stali mikrostopowej zostały poddane procesowi wielostopniowego ciągnienia, w którym niejednorodna, silna akumulacja odkształcenia powoduje wystąpienie efektów rekrystalizacji in situ, co z kolei powoduje lokalny wzrost stopnia rozdrobnienia mikrostrutury w porównaniu z konwencjonalnym procesem ciągnienia (WD Wire Drawing). Druty wytworzone w procesach AAD oraz WD zostały poddane badaniom porównawczym własności mechanicznych oraz analizie mikrostrukturalnej. W celu zapewnienia poprawnej oceny wpływu złożonej ścieżki odkształcenia na rozwój mikrostruktury i własności mechaniczne w ciągnionych drutach, zastosowano symulacje numeryczne $\mathrm{z}$ wykorzystaniem komercyjnego pakietu Abaqus oraz modeli procesu skręcania. Symulacje procesu cyklicznego skręcania wykonano w celu oceny zdolności proponowanego modelu umocnienia odkształceniowego, opartego na zmianach gęstości dyslokacji, do symulacji zmiennej ścieżki odkształcenia podczas procesu AAD. Dodatkowa zaleta zaproponowanego podejścia jest możliwość śledzenia rozwoju gęstości dyslokacji podczas procesu odkształcania. Początkowa gęstość dyslokacji wykorzystana w obliczeniach wyznaczona została $\mathrm{z}$ analizy mikrostrukturalnej z wykorzystaniem wysokorozdzielczej techniki EBSD. Podczas zmiany kierunku odkształcenia, proces anihilacji dyslokacji (efekt Bauschingera) jest częstym zjawiskiem prowadzacym do spadku gęstości dyslokacji, a w konsekwencji do obniżenia umocnienia odkształceniowego. W celu wyznaczenia niejednorodności mikrostrukturalnej oraz niejednorodności odkształcenia $\mathrm{w}$ drutach po procesie ciągnienia, zastosowano modelowanie wielkoskalowe $\mathrm{w}$ połączeniu $\mathrm{z}$ cyfrową reprezentacją obrazu (DMR).

Received: October 14, 2019 Received in a revised form: December 12, 2019. Accepted: December 20, 2019. 